\title{
The quality properties, thiobarbituric acid (TBA) values and microstructure of chicken sausage with local red beetroot powder
}

\author{
1, ${ }^{*}$ Swastike, W., ${ }^{2}$ Suryanto, E., ${ }^{2}$ Rusman, ${ }^{3}$ Hanim, C., ${ }^{2}$ Jamhari, ${ }^{2}$ Erwanto, Y. and ${ }^{4}$ Jumeri \\ ${ }^{I}$ Department of Animal Science, Faculty of Agriculture, Universitas Sebelas Maret, Surakarta, Indonesia. \\ ${ }^{2}$ Deparment of Animal Products Technology, Faculty of Animal Science, Universitas Gadjah Mada, \\ Yogyakarta, Indonesia. \\ ${ }^{3}$ Deparment of Animal Feed and Nutrition, Faculty of Animal Science, Universitas Gadjah Mada, \\ Yogyakarta, Indonesia. \\ ${ }^{4}$ Department of Technology Agricultural Industry, Faculty of Agricultural Technology, Universitas Gadjah \\ Mada, Yogyakarta, Indonesia.
}

\begin{abstract}
Article history:
Received: 7 December 2020 Received in revised form: Accepted: 16 August 2021 Available Online: 31 August 2021
\end{abstract}

\section{Keywords:}

Oxidative stability,

Microstructure,

Chicken sausage and locally red beetroot powder

\section{DOI:}

https://doi.org/10.26656/fr.2017.5(S2).019

\begin{abstract}
This research was aimed to determine the quality properties, the microstructure of chicken sausage and Thiobarbituric acid (TBA) values with locally Indonesia red beetroot powder. The main ingredients of chicken sausage-making in this research were broiler chicken, filler, binder, beetroot powder, and spices. Red beetroot powder function as a filler was substituted tapioca starch in chicken sausage batter in three different levels. The combination of red beetroot powder with level $0,1.0,2.0$ and $3.0 \%$ of total batter and shelf life at room temperature for 0, 1, 2 and 3 days. Each treatment consisted of five replications. The variables observed using quality properties (moisture, ash, fat, protein, crude fiber and calorie), microstructure and peroxide value of chicken sausage. The data of quality properties and peroxide value were analyzed by using one-way analysis (ANOVA) of Completely Randomized Design. The differences between means were analyzed by Duncan's New Multiple Ranges Test. The data of microstructure was analyzed by descriptive analyses. The moisture, protein, fat and ash contents for chicken sausages were significantly different $(\mathrm{p}<0.05)$. The chicken sausage with $2 \%$ substitution of beet powder produced chicken sausages with a high protein content of $14.77 \pm 0.02 \%$ while a low-fat content is $0.42 \pm 0.01 \%$. Thiobarbituric acid (TBA) values of chicken sausages increased throughout the three days of room temperature storage $\left(38^{\circ} \mathrm{C}\right)$. Chicken sausage formulated with red beetroot powder showed a significantly lower TBA value compared to the samples without red beetroot powder $(\mathrm{p}<0.05)$. In conclusion, a higher level of beetroot powder will improve the quality of chicken sausage and also the microstructure. The best level of beetroot powder addition was $2.0 \%$. The addition of beetroot powder able to maintain fresh sausage conditions up to 2 days of storage at room temperature.
\end{abstract}

\section{Introduction}

Chicken meat provides high protein and low fat, and chicken lipids are characterized by relatively high levels of unsaturated fatty acids, which are considered to be positive and healthy by consumers (Hwang et al., 2011). Chicken sausage is a precious product that is widely used as an alternative as a source of protein. The high content of protein and fat made a sausage became a perishable food. Oxidation of lipid and auto-oxidation is one of the major causes of quality deterioration and reduction of shelf life of meat products (Min and Ahn, 2005). This may produce changes in meat quality parameters such as color, texture and even nutritional value (Fernandez et al., 1997; Lima et al., 2013). Synthetic antioxidants such as Butylated hydroxytoluene (BHT) and butylated hydroxyanisole (BHA) have been used extensively to prevent the sausage from oxidation. The concentration of synthetic antioxidants allowed in food is limited to $0.01 \%$ of fat content (when used individually). Nowadays, the acceptability of synthetic additives by consumers is low since certain toxicity and carcinogenicity have been identified in some studies (Faine et al., 2006 ). For these reasons, the interest of the 
meat industry in using natural antioxidants has increased considerably (Kumar et al., 2015). Recent studies have implicated them to have toxic effects (Lindenschmidt et al., 1986; Shahidi et al., 1992), hyperactivity in children, allergies to cancer.

Since the last few decades, public awareness of health and preservation of the global environment has had an impact on people's behavior to consume healthy foods product (Laroche et al., 2001). The increased public awareness of health was expected to have a positive impact on the increase in demand for food natural products. It is because these products are produced using a natural product that produces healthier and safer foods for consumption (Suharjo et al., 2016). The antioxidant is intended to prevent the presumed deleterious effects of free radicals in the human body, and as prevention to the deterioration of fats and other constituents of the food products (Azmi et al., 2019).

Composite flour as an innovative flour that has attracted much attention in research as well as food product development (Hasmadi et al., 2014; Suresh et al., 2015; Gbenga-Fabusiwa et al., 2018; Jafari et al., 2018; Hasmadi et al., 2018; Nyembwe et al., 2018; Emmanuel et al., 2019). Composite flour defined as a mixture of flours obtained from tubers rich in starch (Hasmadi et al., 2020), with or without wheat flour that created to satisfy specific functional characteristics and nutrient composition (Noorfarahzilah et al., 2014).

Red beetroot is a type of tuber plant that is cultivated in highlands, especially in central Java, Indonesia. They used it only as a dressing salad or as consumed in juice. Beetroot is highly acceptable for its rich nutrient contents viz. dietary fiber, mineral contents such as iron, potassium, calcium, zinc, and sodium, and vitamin contents such as vitamin A, B6, folic acid, niacin, biotin and C (Pinki, 2014). Beetroot contains both betaine and nitrate. Betaine is a trimethyl derivative of amino acid glycine which promotes muscular endurance, strength, and power (Hoffman and Ratamess, 2009). Beetroot is a source of natural antioxidant and also natural coloring (Georgiev et al., 2010) because red beetroot contains flavonoid and pigment that brings a lot of function. Consumption of red beet, which is rich in phenolic acids and has a high antioxidant capacity, can help protect against age-related diseases (Ravichandran et al., 2013). some natural compounds have higher antioxidant capacity than synthetic compounds and some also have other positive effects on the sensory properties of meat products ( Kumar et al., 2015). It also can be applied to processing food and or to be food ingredients, even pure beetroot, extract, and or powder. Red beetroot powder can be fortified and or substituted with a filler or binder commonly used in the processing of sausage. Some studies have been carried out on the use of various beetroot for attaining these properties in emulsified type sausages (Jin et al., 2014; Yildiz et al., 2016), and also as a filler (Swastike et al., 2020).

Fillers are starch, which is a carbohydrate polymer derivated from plant-based, able to absorb large quantities of water, but they are not suitable for emulsifiers. The emulsification has shown in the microstructural of the sausage. On the other hand, starches can act as fillers that bind water and fat (Heinz and Hautzinger, 2007). The functionality of different types of starches depends on granular structure, amylose, and amylopectin. Amylose contributed to gel strength and amylopectin in a viscoelastic (Mahmood et al., 2017). The interaction of water, muscle protein, fat globules, and types of starch is the primary factor responsible for the emulsion of meat products (Peraire et al., 2019).

Thus, this study aimed to explore red beetroot powder as a filler and as a natural antioxidant in the quality properties, and microstructure and also Thiobarbituric acid (TBA) values in-room storage of chicken sausage

\section{Materials and methods}

The ingredients used in this experiment were breast chicken meat, beetroot powder, tapioca flour, Isolated Soy Protein (ISP), spices (salt, fresh Garlic, pepper powder), sodium tripolyphosphate (STTP), cooking oil, and ice water.

The material used in this experiment were a grinder, meat chopper, penetrometer, digital electric scale, analytical scales, filter paper, cooking glove, stove, blender, $\mathrm{pH}$ meter, stainless steel pan and knife, thermometer, sausage casing, $35 \mathrm{~kg}$ barbell, millimeter block paper, permanent markers, and stopwatch.

\subsection{Preparation of red beetroot powder}

Red beet (Beta vulgaris L. var. conditiva) roots were bought at Cepogo, Central Java, Indonesia. The red beetroots were washed, peeled, and chopped into small pieces. Chopped red beet was subsequently placed into a freeze dryer. The dried product was grounded, and the final moisture content of the red beet powder was $3.5 \pm 0.5 \%$.

\subsection{Preparation of chicken sausage}

The breast chicken meat, spices, tapioca and beetroot powder in different level were prepared and pondered. Red beetroot powdered that we used was prepared in the 
different level to substituted tapioca flour. The skinless breast meat was purchased from a local retailer. Subcutaneous and excessive connective tissues were removed from the meat and minced through. Four batches were prepared for each treatment; The basic recipe consisted of $65 \%$ meat, tapioca flour $18 \%, 10 \%$ ice water and spices (Garlic, pepper, salt) were added to the completed batter until $100 \%$. Minced meat was ground for $1 \mathrm{~min}$ using a bowl cutter. Mixed all ingredient for 2 mins and continuous with mixer for 15 mins. The other batter had decreased percentages of tapioca flour (1,2 and 3\%) and replaced with substituted red beetroot powder. The batter was then stuffed casings using a stuffer. The stuffed samples were cooked in a heating chamber to an internal temperature of $80^{\circ} \mathrm{C}$. The chicken sausages were then cooled and ready to be evaluated.

\subsection{Chemical analysis}

Moisture, protein (total nitrogen $\times 6.25$ ), ash and fat contents of differently prepared beef sausage samples were determined according to AOAC (2012). Carbohydrates (nitrogen-free extract) were determined by differences.

\subsection{Thiobarbituric acid value (TBA) analysis}

TBA values in chicken sausages were measured following the procedure by Salih et al. (1987) with slight modifications. Exactly $5.0 \mathrm{~g}$ samples (accurate to $0.01 \mathrm{~g}$ ) were mixed with $15.0 \mathrm{~mL}$ of $20 \mathrm{~g} / \mathrm{mL}$ trichloroacetic acid solution and homogenized at $10000 \mathrm{r} / \mathrm{min}$ for 3 mins in an ice bath, deproteinized for $2 \mathrm{hrs}$, centrifuged at $2000 \times g$ for 10 mins at $4^{\circ} \mathrm{C}$, the supernatant was filtered with double slow filter paper, and diluted to $50 \mathrm{~mL}$ with double-distilled water. A $5.0 \mathrm{~mL}$ aliquot of the filtrate was mixed with $5.0 \mathrm{~mL} 0.02 \mathrm{~mol} / \mathrm{L}$ 2-Thiobarbituric acid solution, allowed to react at $90^{\circ} \mathrm{C}$ for $30 \mathrm{mins}$, cooled to room temperature immediately, and absorbance was read at $532 \mathrm{~nm}$. Results were expressed as $\mathrm{mg}$ malondialdehyde (MDA)/kg sample.

\section{Result and discussion}

\subsection{Chemical quality properties of chicken sausage}

The chemical quality properties of the chicken sausages were formulated with different levels of red beetroot powder shown in Table 1 .

\subsubsection{Moisture}

The moisture content of the chicken sausages containing red beetroot powder was higher than without red beetroot powder $(\mathrm{p}<0.05)$. the increase in moisture content might be due to higher moisture present in red beetroot powder. Thus, the increase in the substitution of red beetroot powder caused an increase in the water content of chicken sausage. On the other hand, the substitution of red beetroot powder or replacement of tapioca starch started with the concentration 1, 2, 3\% will affect significantly the water content $(\mathrm{P}<0.05)$. The higher water content also found in the other meat product substituted with texturized vegetable protein (Hidayat et al., 2018). The latter result likely reflected Zargar et al. (2014) also reported an increase in the moisture content in chicken sausage with pumpkin, Suradkar et al. (2013) and Das et al. (2013) also reported an increase in the moisture content of chicken nuggets containing bread crumbs and chicken nuggets containing fermented bamboo shoot, respectively. This was in agreement with the findings of Verma et al. (2010) who also observed a similar finding in designer chicken nuggets incorporated with apple pulp. Similar results were also observed by Nazni and Karuna Thara (2011) where ash and fibre contents were increased with the increment of beetroot powder percentages in the cake.

\subsubsection{Crude protein}

Table 1 shows that the crude protein content of chicken sausages decreasing significantly $(\mathrm{P}<0.05)$, however, the substitution in $2 \%$ level of red beetroot powder almost the same protein with the chicken sausage without red beetroot powder. The probable reasons for the decreased protein content may be attributed to the comparatively lower protein contents of red beetroot powder. Suradkar et al. (2013) also reported a decrease in the protein content of chicken nuggets containing breadcrumbs. Verma et al. (2013) also observed a decrease in the protein content of sheep meat nuggets on the incorporation of guava powder. Taludkar and Sharma (2009) observed a decrease in the protein content of chicken meat patties incorporated with wheat and oat

Table 1. The chemical quality properties of chicken sausage with different substitution level of red beetroot powder

\begin{tabular}{ccccc}
\hline Parameter & \multicolumn{4}{c}{ Different level Substitution of red beetroot powder (\%) } \\
\cline { 2 - 5 }$(\%)$ & 0 & 1 & 2 & 3 \\
\hline Moisture & $64.21 \pm 0.04^{\mathrm{a}}$ & $65.55 \pm 0.02^{\mathrm{c}}$ & $65.44 \pm 0.19^{\mathrm{b}}$ & $66.16 \pm 0.28^{\mathrm{d}}$ \\
Protein & $14.88 \pm 0.01^{\mathrm{c}}$ & $14.65 \pm 0.07^{\mathrm{a}}$ & $14.77 \pm 0.02^{\mathrm{b}}$ & $15.15 \pm 0.02^{\mathrm{d}}$ \\
Fat & $0.50 \pm 0.013^{\mathrm{c}}$ & $0.47 \pm 0.07^{\mathrm{b}}$ & $0.42 \pm 0.01^{\mathrm{a}}$ & $0.40 \pm 0.01^{\mathrm{d}}$ \\
Crude fiber & $0.12 \pm 0.005^{\mathrm{a}}$ & $0.15 \pm 0.005^{\mathrm{b}}$ & $0.18 \pm 0,005^{\mathrm{c}}$ & $0.24 \pm 0.008^{\mathrm{d}}$ \\
\hline
\end{tabular}

Values are presented as mean $\pm \mathrm{SD}, n=5$. Values with different superscript within the same row are significantly different $(P<$ $0.05)$. 
bran.

\subsubsection{Fat content}

The fat content of chicken sausage was gradually decreased significantly $(\mathrm{P}<0.05)$. The fat content was getting lower compared to other substitution levels of red beetroot powder. Verma et al. (2013) also observed a decrease in the fat content of sheep meat nuggets on the incorporation of guava powder. Suradkar et al. (2013), Verma et al. (2012a) and (2012b) also reported similar results in different meat products. Taludkar and Sharma (2009) observed a decrease in the fat content of chicken meat patties incorporated with wheat and oat bran. Similar results were reported by Valeria et al. (2008) for dry fermented sausages prepared by the incorporation of carrot dietary fibers and Aleson-carbonell et al. (2004) for non-fermented dry-cured sausages formulated with lemon albedo. And also, the same with Lucky et al. (2020) observed that fat content and energy decreased respectively, as the percentage of beetroot powder increased from 0 to $20 \%$.

\subsubsection{Crude fiber}

The crude fiber content increased significantly $(\mathrm{P}<$ 0.05 ) with increasing levels of substitution of red beetroot powder. This increase in crude fiber might be due to the high fiber level present in red beetroot powder. A similar increase in the fiber content was also observed by Zargar et al. (2014), Verma et al. (2013), Das et al. (2013), Verma et al. (2012a), (2012b) and Taludkar and Sharma (2009) in various meat products.

\subsection{Thiobarbituric acid value of chicken sausage}

Chicken sausage products contain protein and fat that can cause damage to the product due to oxidation. Oxidation is an indication that the product is under the same or off-flavor, and this condition can result in discoloration, nutritional value and taste. The 2thiobarbituric acid (TBA) is used to measure secondary products of lipid oxidation primarily derived from PUFA) and indicate a preoccupation (Chen et al., 2014). According to Eneke et al. (2018), TBA values decreased within the first 2 months suggesting that conditions for initiation of auto-oxidation were lacking or that TBA reacting substances progressively formed complexes with other compounds. The TBA number on the sausage was shown in Table 2.

Table 2 shows that TBA was higher slightly up until the $2^{\text {nd }}$ day of storage and then increased exponentially on the $3^{\text {rd }}$ day of storage. TBARS content was higher in chicken sausages without substitution red beetroot powder. The chicken sausage with substitution red beetroot powder succeeded inhibit the increase of
TBARS Value until 2 days in room storage. This result was found due to the presence of antioxidants component of red beetroot powder. It is also similar to Khan and Saghir (2015) that the antioxidant content of carrot powder can reduce the degree of fat oxidation.

Table 2. TBA value of chicken sausage with different substitution level of red beetroot powder

\begin{tabular}{ccccc}
\hline \multirow{2}{*}{ Days-n } & \multicolumn{4}{c}{ Different level Substitution of red beetroot powder } \\
\cline { 2 - 5 } & 0 & 1 & 2 & 3 \\
\hline 0 & $0.45 \pm 0.01^{\mathrm{a}}$ & $0.52 \pm 0.02^{\mathrm{b}}$ & $0.58 \pm 0.02^{\mathrm{c}}$ & $0.67 \pm 0.01^{\mathrm{d}}$ \\
1 & $1.82 \pm 0.80^{\mathrm{a}}$ & $1.7 \pm 0.14^{\mathrm{b}}$ & $1.18 \pm 0.09^{\mathrm{b}}$ & $1.79 \pm 0.02^{\mathrm{b}}$ \\
2 & $2.49 \pm 0.02^{\mathrm{c}}$ & $2.14 \pm 0.04^{\mathrm{b}}$ & $1.82 \pm 0.07^{\mathrm{a}}$ & $2.92 \pm 0.04^{\mathrm{d}}$ \\
3 & $4.5 \pm 0.83^{\mathrm{d}}$ & $3.11 \pm 0.74^{\mathrm{b}}$ & $3.16 \pm 0.07^{\mathrm{a}}$ & $3.62 \pm 0.32^{\mathrm{c}}$ \\
\hline
\end{tabular}

Values are presented as mean $\pm \mathrm{SD}, n=5$. Values with different superscript within the same row are significantly different $(P<0.05)$.

The TBA value was also increasing gradually in patties with BHT $0.1 \mathrm{~g} / \mathrm{kg}$ in the refrigerator from the $11^{\text {th }}$ day to the $14^{\text {th }}$ day. The increasing TBARS value was $0.5 \mathrm{mg} / \mathrm{kg}$ into $3.6 \mathrm{mg} / \mathrm{kg}$ (Sabranek et al., 2005). The maximum use of BHA on USDA permitted fresh sausages (2000) is $0.1 \mathrm{~g} / \mathrm{kg}$. TBA levels permitted based on SNI no. 2352-1991 on TBA Determination state that the maximum product limit is $3 \mathrm{mg} / \mathrm{kg}$ sample, and the maximum peroxide is $10 \mathrm{mg} \mathrm{eq} / \mathrm{kg}$.

\subsection{Microstructure of chicken sausage}

The microstructure of chicken sausage is shown in Table 3. Pre-emulsification is the process of producing an oil-in-water emulsion (in the meat batter system) stabilized with an emulsifier (Kang et al., 2016). This process could enhance emulsion stability and make ingredients more evenly disperse in the sausage. It was reported that pre-emulsifying oil with a non-meat protein made more meat proteins available for gel structure formation in the continuous phase of the meat batters (Youssef and Barbut, 2011)

The color of the purplish spot is an interpretation of the balance of amylose and amylopectin found in chicken sausage fillers. So, it can be seen that the substitution level that has a purple spot is more evenly distributed (Table 3). Based on Table 3, then the most ideal homogeneity in a row is chicken sausage with a level of substitution red beetroot powder $0>1>2>3$. The best microstructure was shown to be tighter than the prepared cavity (Aryanti, 2006) while Barbut (2002) explained that proteins can form different gels depending on $\mathrm{pH}$ concentration, ion strength, and temperature.

The factor that affects microstructure is moisture content. The higher water content of the sausage has a positive impact that made the sausage softer than control. If the water content is low it will be harder for the 
sample. Increasing the level of bits will increase the moisture content (Table 1). The porosity of the material can also occur in samples cooked with sudden pressure changes, resulting in sudden puffing that causes the sample to become porous and have cavities (Rahayoe, 2009). Protein believed to be mostly responsible for functional properties, such as foaming, emulsification, nitrogen solubility, oil, and water absorption (Kinsella, 1979). These properties are affected by the intrinsic factors of protein, such as molecular structure and size, and many environmental factors, including the method of protein separation or production ( $\mathrm{Yu}$ et al., 2007). According to Kinsella (1979), functional properties are the significant physicochemical properties that are determining the complex interaction between the composition, structure, and molecular conformation.

Table 3. The microstructure of chicken sausage with enlarge 10 times and 100 times

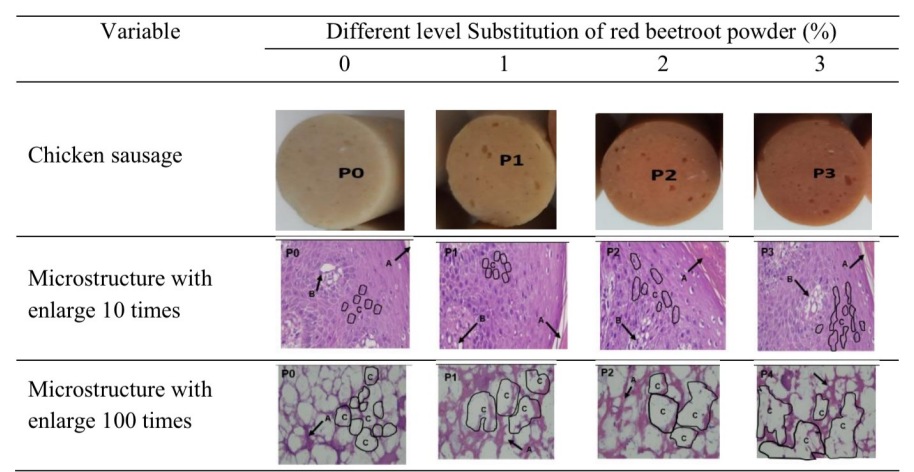

A: protein matrix; B: air doplet; C: Emulsified of protein and starch; Purple Spot: starch from flour and or red beetroot powder as a filler. P0 (substitution red beetroot powder $0 \%$ ), P1 (substitution red beetroot powder 1\%), P2 (substitution red beetroot powder 2\%), and P3 (substitution red beetroot powder 3\%).

\section{Conclusion}

Based on this study, chicken sausage with the substitution of $2 \%$ red beetroot powder not only act as a filler that can improve its chemical quality but can also be a source of natural antioxidants and can inhibit the rate of damage to products due to oxidation during storage. The addition of beetroot powder able to maintain fresh sausage conditions up to 2 days of storage at room temperature.

\section{References}

AOAC. (2012). Official Methods of Analysis of the Association of Official Analytical Chemistry (AOAC) International. 19th ed. Gaithersburg, Maryland, USA: AOAC.

Azmi, N.S., Kadir Basha, R., Othman, S.H. and Mohammed, M.A.P. (2019). Characterization of antioxidant tapioca starch/polyaniline composites film prepared using solution casting method. Food Research, 3(4), 317-324. https://doi.org/10.26656/ fr.2017.3(4).144

Das, A, Nath, D.R., Kumari, S. and Saha, R. (2013). Effect of fermented bamboo shoot on the Quality and shelf life of nuggets prepared from desi spent hen. Veterinary World, 6(7), 419-423. https:// doi.org/10.5455/vetworld.2013.419-423

Eneke, B.M., Attaugwu, R.N., Ufondu, H.E. and Uvere, P.O. (2018). Nutritional stability of instant Kunun zaki flours produced from millet-malted cowpea and millet-malted soybean during the 3 months storage. Food Research, 2(1), 56-60. https:// doi.org/10.26656/fr.2017.2(1).115

Faine, L.A., Rodrigues, H.G., Galhardi, C.M., Ebaid, G.M.X., Diniz, Y.S., Fernandez, A.A.H. and Novelli, E.L.B. (2006). Butyl hydroxytoluene (BHT)-induced oxidative stress: Effects on serum lipids and cardiac energy metabolism in rats. Experimental and Toxicologic Pathology, 57(3), 221-226. https:// doi.org/10.1016/j.etp.2005.10.001

Fernandez, J., Perez-Alvarez, J.A. and Fernandez-Lopez, J.A. (1997). Thiobarbituric acid test for monitoring lipid oxidation in meat. Food Chemistry, 59(3), 345353. https://doi.org/10.1016/S0308-8146(96)00114-8

Hasmadi, M., Matanjun, P., Ibrahim, S., Md. Amin, S.F., Abdul Hamid, M. and Rameli, A.S. (2014). The effect of seaweed composite flour on the textural properties of dough and bread. Journal of Applied Phycology, 26, 1057-1062. https://doi.org/10.1007/ s10811-013-0082-8

Hasmadi, M., Jahurul, M.H.A. Mohamad Khairi, Z. and $\mathrm{Yu}$, A.L. (2018). The influence of seaweed composite flour on the quality of muffin. Journal of Aquatic Food Product Technology, 27(5), 635-642. https://doi.org/10.1080/10498850.2018.1468841

Hidayat, B.T., Wea, A. and Andriati, N. (2018). Physicochemical, sensory attributes and protein profile by SDS-PAGE of beef sausage substituted with texturized vegetable protein. Food Research, 2 (1), 20 -31. https://doi.org/10.26656/fr.2017.2(1).106

Kang, Z.L., Chen, F.S. and Ma, H.J. (2016) Effect of pre -emulsified soy oil with soy protein isolate in frankfurters: a physical-chemical and Raman spectroscopy study. LWT, 74, 465-471. https:// doi.org/10.1016/j.lwt.2016.08.011

Khan, I. and Ahmad, S. (2015). Studies on Physicochemical Properties of Cooked Buffalo Meat Sausage as Influenced by Incorporation of Carrot Powder during Refrigerated Storage. Journal of Food Processing and Technology, 6(4), 1000436.

Kinsella, J.E. (1979). Functional properties of soy 
proteins. Journal of the American Oil Chemists' Society, 56(3 Part 1), 242-258. https:// doi.org/10.1007/BF02671468

Kumar, Y., Yadav, D.N., Ahmad, T. and Narsaiah, K. (2015). Recent Trends in the Use of Natural Antioxidants for Meat and Meat Products. Comprehensive Reviews in Food Science and Food Safety, 14(6), 796-812. https://doi.org/10.1111/15414337.12156

Laroche, M., Bergeron, J. and Barbaro-Forleo, G. (2001). Targeting Consumers Who Are Willing to Pay More for Environmentally Friendly Products. Journal of Consumer Marketing, 18(6), 503-520. https://doi.org/10.1108/EUM0000000006155

Lima Junior, D.M., Nascimento Rangel, A.H., Urbano, S.A. and Moreno, G.M.B. (2013). Oxidação lipídica da carne ovina. Acta Veterinaria Brasilica, 7, 14-28. [In Brazilian].

Lindenschmidt, R., Tryka, A.F., Goad, M.E. and Witschi, H.P. (1986). The effects of dietary butylated hydroxytoluene on liver and colon tumor development in mice. Toxicology, 38(2), 151-160. https://doi.org/10.1016/0300-483X(86)90116-2

Mahmood, K., Kamilah, H., Shang, P.L., Sulaiman, S., Ariffin, F. and Alias, A.K. (2017). A Review: Interaction of Starch/Non-Starch hydrocolloid blending and the recent food applications. Food Bioscience, 19, 100-120. https://doi.org/10.1016/ j.fbio.2017.05.006

Min, B. and Ahn, U. (2005). Mechanism of lipid peroxidation in meat and meat products - a review. Food Science and Biotechnology, 14, 152-163.

Nazni, P. and Karuna Thara, D. (2011). Optimization of beetroot peel osmotic dehydration process using response surface methodology. International Journal of Current Research, 3(8), 27-32

Salih, A.M., Smith, D.M., Price, J.F. and Dawson, L.E. (1987). Modified extraction 2-thiobarbituric acid method for measuring lipid oxidation in poultry. Poultry Science, 66(9), 1483-1488. https:// doi.org/10.3382/ps.0661483.

Shahidi, F., Janitha, P.K. and Wanasundara, P.D. (1992). Phenolic antioxidants. Critical Reviews in Food Science and Nutrition, 32(1), 67-103. https:// doi.org/10.1080/10408399209527581

Suharjo, B., Ahmady, M. and Ahmady, M.R. (2016). Indonesian Consumers' Attitudes towards Organic Products. Advances in Economics and Business, 4 (3), 132-140. https://doi.org/10.13189/ aeb.2016.040303

Suradkar, U.S, Bumla, N.A., Maria, A., Zanjad, P.N. and Sofi, A.H. (2013). Effect of incorporation of bread crumbs on the physicochemical and sensory Quality of chicken nuggets. International Journal of Food Nutrition and Safety, 3(1), 1-6.

Swastike, W., Suryanto, E., Rusman, Hanim, C., Jamhari, Erwanto, Y. and Jumari (2020). The Substitution Effects of Tapioca Starch and Beetroot Powder as Filler on The Physical and Sensory Characteristics of Chicken Sausage. Jurnal Ilmu dan Teknologi Hasil Ternak, 15, 97-107. https:// doi.org/10.13189/aeb.2016.040303

Taludkar, S. and Sharma, D.P. (2009). Development of dietary fiber rich chicken meat patties using wheat and oat bran. Journal of Food Science and Technology, 47, 224-229. https://doi.org/10.1007/ s13197-010-0027-z

Tarladgis, B.G., Watts, B.M., Younathan, M.T. and Dungan, L, Jr. (1960). A distillation method for the quantitative determination of malanoldehyde in muscle foods. Journal of the American Oil Chemist's Society, 37(1), 44-48. https://doi.org/10.1007/ BF02630824

Verma A.K., Sharma, B.D. and Banerjee, R. (2012b). Quality characteristics of low-fat chicken nuggets: effect of common salt replacement and added bottle gourd (Lagenaria siceraria L.). Journal of the Science of Food and Agriculture, 92(9), 1848-1854. https://doi.org/10.1002/jsfa.5691

Verma A.K., Sharma, B.D. and Banerjee, R. (2010). Effect of sodium chloride replacement and apple pulp inclusion on the physico-chemical, textural and sensory properties of low fat chicken nuggets. $L W T$ Food Science and Technology, 43(4), 715-719. https://doi.org/10.1016/j.lwt.2009.12.006

Verma A.K., Banerjee, R. and Sharma, B.D. (2012a) Quality of low fat chicken nuggets: effect of sodium chloride replacement and added chickpea (Cicer arietinum L.) hull flour Asian-Australasian Journal of Animal Sciences, 25(2), 291-298. https:// doi.org/10.5713/ajas.2011.11263

Verma A.K., Rajkumar, V., Banerjee, R., Biswas, S. and Das, A.K. (2013). Guava (Psidium guajava L.) powder as an antioxidant dietary fibre in sheep meat nuggets. Asian-Australasian Journal of Animal Sciences, 26(6), 886-895. https://doi.org/10.5713/ ajas.2012.12671

Youssef, M.K. and Barbut, S. (2011). Fat reduction in comminuted meat products-effects of beef fat, regular and pre-emulsified canola oil. Meat Science, 87(4), 356-360. https://doi.org/10.1016/ j.meatsci.2010.11.011

Yu, J., Ahmedna, M. and Goktepe, I. (2007). Peanut protein concentrate: Production and functional 
properties as affected by processing. Food Chemistry, 103(1), 121-129. https://doi.org/10.1016/ j.foodchem.2006.08.012

Zargar, F.A., Kumar, S., Bhat, Z.F. and Kumar, P. (2014). Effect of pumpkin on the quality characteristics and storage quality of aerobically packaged chicken sausages. SpringerPlus, 3, 39. https://doi.org/10.1186/2193-1801-3-39 